\title{
QUALITATIVE AND QUANTITATIVE ANALYSIS OF MICRO AND MACRO ASPECTS OF AGRICULTURAL FINANCE
}

\author{
Branislav Veselinović1, Maja Drobnjaković2
}

\begin{abstract}
Summary
The epicenter of this analysis is to provide an overview of the current situation in micro and macro agricultural finance in Serbia and the EU. One of the goals of this research is to consider the weaknesses and potentials of agricultural policy in Serbia, through comparison with more developed countries. In this qualitative and quantitative analysis, authors used comparation method, analysis and synthesis method, inductive and deductive method, and a local and international literature review. There are several important conclusions which can be drawn from this manuscript. Access to finance among farmers and agricultural SMEs is among the poorest of any sector in Serbia. The Serbian financial sector offers a poor range of loan products to the agricultural sector. Therefore, existing mechanisms for micro and macro agricultural finance in Serbia are not adequate and a change should be made in approach.
\end{abstract}

Key words: agriculture, finance, Serbia, EU, harmonization.

JEL: F15, F36, Q14.

\section{Introduction}

For the past decades, Serbian agriculture cannot keep pace with the agricultural development of the developed West European countries- neither in technical/technological, nor organizational aspect (Pejanović et al., 2006). The same can be said of its overall efficacy and productivity. Consequences of a long-term disinvestment in the agricultural sector are more pronounced than ever (Babović and Veselinović, 2010). Observing the current situation, credit support to the agriculture of Serbia through the banking sector is extremely unfavorable. Average active interest rates in Serbia are considerable higher than average active interest rates in the European Union and neighboring countries. Especially in times of global crisis, it is extremely important to provide more favorable credit conditions and thus

1 Branislav Veselinović, Ph.D., Full Professor, The Faculty of Economics and Engineering Management - University Business Academy in Novi Sad, Cvećarska Street no. 2, 21000 Novi Sad, Republic of Serbia, Phone: +381 63505 350, E-mail: bveselinovic@fimek.edu.rs

2 Maja Drobnjaković, M.A., Assistant, The Faculty of Economics and Engineering Management - University Business Academy in Novi Sad, Cvećarska Street no. 2, 21000 Novi Sad, Republic of Serbia, Phone: +381 6423760 32, E-mail: majadrobnjakovic@fimek.edu.rs

EP 2014 (61) 3 (771-787) 
stimulate taking loans for investments in agriculture (Reyes et al., 2012). On the other hand, financial support to agriculture through the agrarian budget, even under more favorable credit conditions, is not enough for self-sustainability (Radović, 2009). Lack of financial resources is a key limiting factor of the efficient utilization of agricultural resources - in transitional countries and developed ones alike (Ciaian et al., 2010). Despite the rich tradition and natural resources, the agriculture of Serbia is financially incapable of investing in new technologies, equipment, knowledge and innovations and, consequently, its competitiveness is seriously impaired, not only in international but domestic market as well. Solution to the problem of financing agriculture implies finding the answer to the question whether Serbia chooses the strategy of self-sufficiency in food industry or perceives the development of a whole agriculture complex as export-oriented and potentially prosperous industry (Veselinović et al., 2007). Surely, financial mix in the sector of agriculture is significantly different from the financial mix in other industries, due to certain specificities (Mondelli, 2012). There are many alternative usages of financial capital and investments in agriculture should be rated as a priority in order to strengthen rural economy and help it become independent (Curtiss, 2012).

\section{Methodology and data sources}

During the analysis, authors used compilation and comparation method, analysis and synthesis method, inductive and deductive method, and desktop study. Most important aspects were presented graphically and tabular and analyzed characteristics were presented in absolute and relative numbers. Methods used are in accordance with the research goals (consider the "pros" and "cons" of agricultural policy in Serbia, through comparison with EU), so they provide a real image of the situation within the national agriculture. During the manuscript preparation, all the available data sources were used, ranging from available statistical data of the Statistic offices of Republic of Serbia and EU, current literature, scientific papers, and electronic databases. It should also be noted that the statistical evidence offered by National Statistic Offices and EU publications, related to the performances in agriculture sector, is often not up to date, methodologically and value aligned with data from other relevant sources. This is the major reason for the possible value fluctuation and deviation, particularly for data that are results of estimates.

\section{Results - part I: agriculture policy in Serbia}

With the reconstruction of credit and monetary system, which started on 24 January, 1994, the financing of agriculture from the primary emission of the National Bank of Yugoslavia was abolished with the explanation that these placements of funds affect the growth of the domicile inflation rate. Under such circumstances, it was necessary to find new modes of financing considering the specificities of agriculture. At the same time, due to the restricted amount of money, interest rates on credits granted by business banks started growing, which significantly made production more expensive and brought agricultural enterprises in a difficult financial situation. Due to the mentioned reasons, there was a need for establishing a secure and permanent source of agriculture financing, which led to the establishment of the agrarian budget, as a constituent part of the national budget. 
In the year 1993, hyperinflation was recorded in domestic economy, which significantly influenced the extremely high interest rates in the financial market. According to some sources, the primary emission resources directed through selective credits to agriculture were insufficient in comparison with the needs of agriculture. These placements of funds were reduced because of the low level of rediscount and also because of the base to which it was applied (Radović, 2009). At the beginning of 1996, the agrarian budget officially became an integral part of the state budget. The agrarian budget was projected as an overall source of state support to the agricultural sector for maintaining current production levels, but also enables certain developmental initiatives of this business activity. The initial idea was for the agrarian budget to provide stimulation for the priority needs of agriculture, professional agricultural service and village revival. However, financial means that were allocated for this purpose were simply not sufficient.

As it was previously mentioned, the agricultural credit market cannot operate without state intervention, not even in the economically developed countries. We can draw a few general conclusions, from the analysis of these state interventions:

- Most transitional countries introduced some form of government guarantees, wishing to stimulate crediting of the agricultural sector,

- Most transitional countries increased the level of subsidized credits,

- A certain number of transitional countries established specialized agricultural banks, which were later privatized and got the permission to get diversified (in most cases, governments used these institutions for directing subsidized short-term credits, with gradual change of orientation towards giving guarantees throughout the financial sector).

The effects of such government interventions were the following:

- Credit subsidies do not stimulate greater availability of credits, if the question of collateralization has not been appropriately resolved,

- Indebtedness of the agricultural sector in transitional countries continuously increased, rather than decreased, as it had been expected, thus inducing a higher degree of government interventions in the credit market ("vicious circle"),

- Once undertaken government interventions show a repeating tendency

When analyzing and comparing the results of state interventions within the financial market, it is important to acknowledge the fact that the highest percentage of these programs essentially tries to treat the symptoms rather than causes of problems. The problem of financing agriculture appears as a reaction to unfavorable macro-economic situation (inflation, public debt, and foreign trade deficit), inappropriate land regulations, lack of effective economic market and amount of transaction costs due to the present risk of financing agriculture. 
Table 1. The share of agrarian budget in the national budget of the Republic of Serbia (Values expressed in billions of EUR)

\begin{tabular}{|c|r|r|r|}
\hline \multirow{2}{*}{ Year } & \multirow{2}{*}{$\begin{array}{c}\text { National budget of } \\
\text { the Republic of Serbia }\end{array}$} & \multicolumn{2}{|c|}{$\begin{array}{c}\text { Agrarian budget of } \\
\text { the Republic of Serbia }\end{array}$} \\
\cline { 3 - 5 } & & Amount allocated from & Percentage share \\
\hline 2007 & 7.52 & 0.27 & 3.60 \\
\hline 2008 & 7.85 & 0.31 & 3.97 \\
\hline 2009 & 7.51 & 0.17 & 2.22 \\
\hline 2010 & 7.23 & 0.19 & 2.61 \\
\hline 2011 & 8.09 & 0.19 & 2.36 \\
\hline 2012 & 7.69 & 0.18 & 2.28 \\
\hline 2013 & 9.49 & 0.36 & 3.78 \\
\hline
\end{tabular}

Source: Authors' calculation, based on data from the website of the Ministry of Finance of the Republic of Serbia (Budgeting Laws of the Republic of Serbia for respective years).

Graph 1. Movement of percentage share of agrarian budget in the national budget of Serbia for the period 2007 - 2013
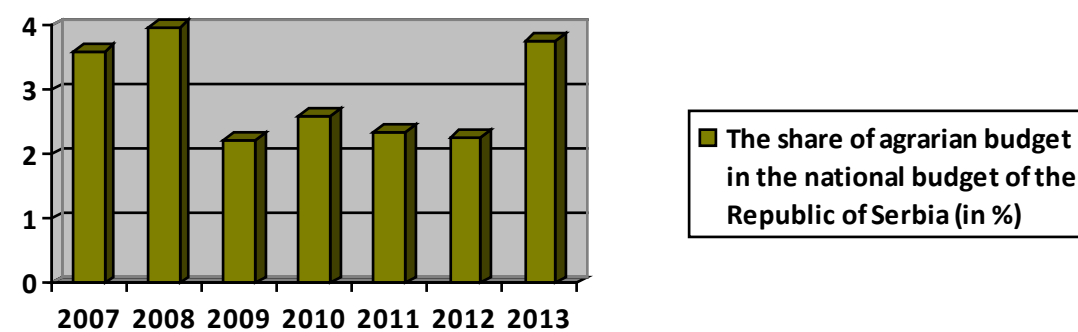

Source: Authors.

The financing of current agricultural production and additional investments from debt sources is a common thing, not only in domestic agriculture, but in general. The reason for this lies in the specificities of agricultural activities, i.e. in biological characteristics of production and duration of production cycle, which lead to a pronounced imbalance of financial income and expenditures. Agricultural production is characterized by a high level of seasonality which frequently leads to periodical imbalances between expenditures in the planting and revenues in the harvesting seasons. For this reason, loans with flexible loan repayment schedules harmonized with agricultural production cycles are often stipulated in the agricultural economics literature (Weber et al., 2014). When speaking of banking credits as foreign financing sources, it is important to highlight the difference between short-term loans designated for current liquidity and working capital financing and long-term loans designated for investments. For users of banking credit, it is an important rule that assets are linked to the term of investment, i.e. that short-term financial resources are not used for long-term investments, and vice versa. In order to change the way financial institutions perceive agriculture, as a high risk sector, we should introduce continuous measurement and monitoring of risk 
in agriculture (Morgan et al., 2011). However, not even in economically developed countries the market for agricultural credits is not totally efficient (Swinnen and Gow, 1997). What is more, it cannot operate independently, without state intervention (Stiglitz et al., 1994). Several researches confirm that financing constraints affect farmers' investment decisions through an excess reliance on internal farm funds for investment. The constraints increase significantly and become much more acute following the financial and economic crisis. Some researchers find that financial constraints do impact investment, but the level and extent of the effect is dependent on the structure of the capital market as well as the overall macro-credit cycle (O'Toole et al., 2014). Some examples of reasons for rejecting a loan applicant are: "Insufficient farm business income", "Poor credit history of the applicant" and "Lack of collateral" (Hedman and Lagerqvist, 2013). It can be difficult for the farmer to use assets as collateral for several reasons: in proprietary farms there is a lack of differentiation between business assets and private assets and the farmer's machinery is not always possible to liquidize on a second-hand market. In other words: not all assets in a farm would be possible to use as collateral (Hedman and Lagerqvist, 2013).

\section{Results - part II: comparative analysis}

For Serbia, the process of joining the European Union represents a huge challenge. Positive experiences of countries which have already become part of the EU are only partially applicable to Serbia. Factors which degrade the status of Serbia are connected with the "ad hoc" concept of agrarian policy, lack of capital base, centralized system of public finances and lack of financial resources at regional and municipal levels, varying scope and quality of raw materials production, poor/weak banking system, slow building of the economic infrastructure and also slow adjustments with respect to the legislative framework. On the other hand, the advantages of domestic agriculture are long tradition, rich and diverse land resources as well as price competitiveness. Stagnation in integration processes weakens the domestic agriculture, unlike the agriculture of developed countries and thus presents a threat to maintaining the current position, and especially to any significant growth. The process of agricultural reforms in transitional countries is determined by their starting positions and also the pace and scope of reforms. A fundamental difference between the European model of agriculture and agriculture of non-European competitors lies exactly in the multi-purpose nature of agriculture in the European Union and its significant role in economy, society, living environment and contribution to the income of people from rural areas. The common agricultural policy presents the most expensive policy, from the perspective of the central budget of the EU (of the total structure, the Common agricultural policy makes $44 \%$ of the central EU budget). 
Table 2. The share of agrarian budget in the central budget of the EU (Values expressed in billions of EUR)

\begin{tabular}{|c|c|c|c|}
\hline \multirow[b]{2}{*}{ Year } & \multirow[b]{2}{*}{$\begin{array}{l}\text { Central budget of } \\
\text { The European Union }\end{array}$} & \multicolumn{2}{|c|}{ Agrarian budget of the $\mathrm{EU}$} \\
\hline & & $\begin{array}{l}\text { Amount of financial resources } \\
\text { from the central budget }\end{array}$ & Share (in \%) \\
\hline 2007 & 126.5 & 56.30 & 44.50 \\
\hline 2008 & 129.1 & 55.00 & 42.60 \\
\hline 2009 & 133.7 & 52.50 & 39.30 \\
\hline 2010 & 141.5 & 43.86 & 31.00 \\
\hline 2011 & 141.9 & 42.57 & 30.00 \\
\hline 2012 & 147.2 & 44.00 & 29.90 \\
\hline 2013 & 150.9 & 44.00 & 29.10 \\
\hline
\end{tabular}

Source: Authors' calculation, based on data from the website of the European Commission (Financial Framework 2007 - 2013).

One of the biggest weaknesses of the agriculture of Serbia is precisely financing. The two main shortcomings of the domestic agriculture policy are: a low level of budget allocation aimed at stimulating the development of agriculture (low agricultural budget), as well as annual level of finances allocated for agriculture with frequent changes of selection or amount of measures. On the other hand, one of the main characteristics of the Common agricultural policy is the concept of seven-year financing plans, which have been further divided into annual sub-plans, with precisely determined amounts of subsidies, potential users and purposes. This way, all participants in process of production, processing and food products placement, are guaranteed predictability, stability and consistency in agriculture policy, which are crucial preconditions of successful business operations. Long-term qualitative policy is necessary for Serbia to create a secure and attractive environment for the domestic and foreign investors in the agricultural business area.

Graph 2. Percentage share of agrarian budget in the central budget of the EU in the period 2007 - 2013 (decreasing tendency)

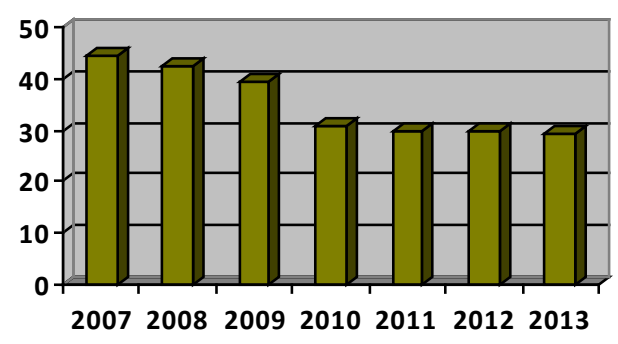

The share of agrarian budget in the central budget of the EU (in \%)

Source: Authors.

If we simultaneously compare the movement of agricultural share in the central budget of Serbia on the one hand, and the European Union- on the other, we come to an obvious conclusion that financial allocations for agriculture were ten times bigger in the EU 
than in our country, Serbia. However, the percentage share of budget designated for financing the Common agricultural policy within the structure of the total budget of the EU significantly decreases with time. One of the possible explanations for this is also a movement towards the so-called "weightless economy" (giving advantage to investments in intangible assets in time of the "knowledge economy") and gradual abandonment of traditional models of business ("tangible" production). On the other hand resources being allocated for agriculture in Serbia are not sufficient to provide the development and improvement of this sector. However, the share of agricultural in the total national budget of Serbia does not show a decreasing tendency, nor does it show an increasing tendency above the modest 5 per cent (which is a paradox, given that agricultural area covers around 60 per cent of the total territory of Serbia, and 43 per cent of the total population of Serbia lives in rural areas). Hence, there is an evident imbalance between the existing natural resources/potentials and defined hierarchy of development objectives (wrong directing).

Graph 3. Comparative analysis of the share of agrarian in the central budget between Serbia and the European Union in the period 2007 - 2013
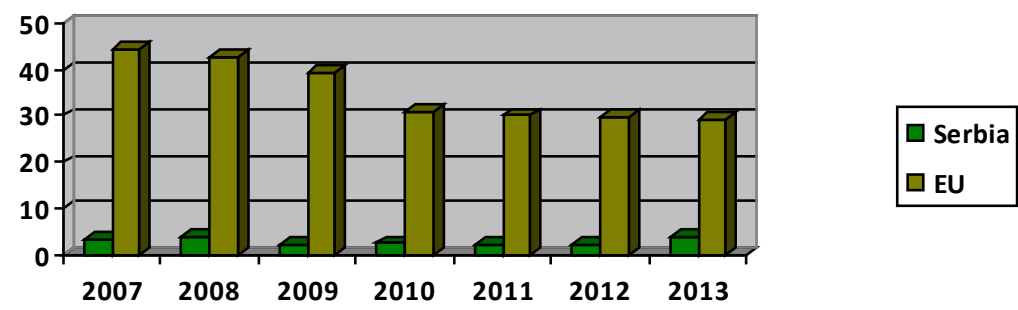

Source: Authors.

Without any doubt, we should learn from other people's mistakes, but not uncritically apply other countries' experiences to the domestic situation at the current stage of agricultural and rural development and preparations for accession to the EU. Strategies for restructuring of the agricultural sector and agricultural policies of transitional countries largely differed between one another. The Baltic countries (Estonia, Latvia and Lithuania) and Poland implemented the so-called "shock therapy" at the beginning of the transitional period. During this period, agrarian support and import protection were drastically reduced; national economy was open to international competition and farming estates were more taxed than stimulated. On the other hand, the Czech Republic, Slovakia and Hungary gradually adjusted and reformed their agriculture policies. The greatest benefits from reform come from moving from market price support (MPS) to other forms of support. This is most evident in Switzerland, where a gradual process of reinstrumentation of policy away from MPS to payments not requiring production has significantly reduced the production and trade distorting impacts of agricultural policy (Martini, 2011). 
Table 3. Amount of budget for support to the agriculture of Slovenia in the period 2007 - 2010 (Expressed in millions of EUR)

\begin{tabular}{|c|c|}
\hline Year & Budget for support to agriculture \\
\hline 2007 & 379,908 \\
\hline 2008 & 446,321 \\
\hline 2009 & 479,220 \\
\hline 2010 & 427,982 \\
\hline
\end{tabular}

Source: Radović, 2011, p. 111.

Farm businesses generally present a less complex setting for capital structure than do large corporate firms. Internal equity and debt are the major financing alternatives, while external equity and direct access to capital markets are beyond the reach of most farms. Nonetheless, capital intensity of farm businesses is high, production cycles can be lengthy and seasonal, life cycle effects are present, and rates of return on assets are relatively low and volatile (Zhao et al., 2008). Last year, the National Regional Development Agency carried out research on a sample of 21 companies from the sector of agriculture, forestry and fishery (with the highest total income recorded in 2010), which they used to analyze the influence of the world economic crisis on this sector. The most dramatic signal of financial instability also hitting agriculture was the sudden worsening of the financial leverage rate. In 2008, the leverage rate rise by almost 4 percentage points to $18 \%$. Before 2008 , it had remained quite stable, ranging annually between 13 and 16\%. The 4 percentage-point rise observed in 2008 was twice the 2 percentage-point rise observed during the economic recession in the late 1980s and early 1990s (Pietola et al., 2011).

Table 4. Financial indicators for the sector of agriculture, forestry and fishery (the case of Serbia), (Expressed in 000 RSD)

\begin{tabular}{|l|r|r|r|r|}
\hline \multicolumn{1}{|c|}{ Indicator } & \multicolumn{1}{c|}{$\mathbf{2 0 0 7}$} & \multicolumn{1}{c|}{$\mathbf{2 0 0 8}$} & \multicolumn{1}{c|}{$\mathbf{2 0 0 9}$} & \multicolumn{1}{c|}{$\mathbf{2 0 1 0}$} \\
\hline Share of financing responsibilities & 54.88 & 57.13 & 58.37 & 62.52 \\
\hline Coverage of long-term assets by capital & 1.12 & 0.97 & 0.92 & 0.93 \\
\hline Coefficient of current liquidity & 1.20 & 1.18 & 1.04 & 1.04 \\
\hline Stock turnover coefficient & 3.49 & 3.96 & 3.66 & 3.76 \\
\hline Coefficient of accounts receivable turnover & 8.02 & 8.06 & 7.05 & 7.01 \\
\hline Economical business operations & 1.03 & 0.99 & 0.95 & 0.98 \\
\hline Return on Assets (ROA) & 3.94 & 1.73 & 1.55 & 0.88 \\
\hline Net margin & 2.41 & -3.99 & -3.71 & -1.87 \\
\hline Financial expenditures & 985,956 & $1,834,738$ & $2,393,593$ & $3,198,422$ \\
\hline Earnings before income and tax (EBIT) & 324,737 & 367,040 & 214,633 & 188,897 \\
\hline Total revenues & $35,963,260$ & $43,019,252$ & $46,248,248$ & $62,362,612$ \\
\hline
\end{tabular}

Source: National Regional Development Agency, 2012, p. 29. 
Table 5. Financial indicators for the sector of agriculture, forestry and fishery (the case of Slovenia), (Expressed in EUR)

\begin{tabular}{|l|r|r|r|r|}
\hline \multicolumn{1}{|c|}{ Indicator } & \multicolumn{1}{c|}{$\mathbf{2 0 0 7}$} & \multicolumn{1}{c|}{$\mathbf{2 0 0 8}$} & \multicolumn{1}{c|}{$\mathbf{2 0 0 9}$} & \multicolumn{1}{c|}{$\mathbf{2 0 1 0}$} \\
\hline Share of financing responsibilities & 41.05 & 42.82 & 45.48 & 46.10 \\
\hline Coverage of long-term assets by capital & 0.96 & 0.97 & 0.92 & 0.92 \\
\hline Coefficient of current liquidity & 1.62 & 1.68 & 1.68 & 1.61 \\
\hline Stock turnover coefficient & 11.98 & 11.60 & 10.34 & 11.92 \\
\hline $\begin{array}{l}\text { Coefficient of accounts receivable } \\
\text { turnover }\end{array}$ & 5.78 & 5.95 & 5.27 & 5.34 \\
\hline Economical business operations & 1.06 & 1.00 & 0.98 & 1.00 \\
\hline Return on Assets (ROA) & 4.05 & 1.07 & -1.19 & 0.06 \\
\hline Net margin & 3.34 & -0.86 & -3.37 & -0.69 \\
\hline Financial expenditures & $5,581,129$ & $7,535,321$ & $5,874,774$ & $4,303,254$ \\
\hline Earnings before income and tax (EBIT) & $2,886,747$ & $(998,594)$ & $(3,194,007)$ & $1,825,150$ \\
\hline Total revenues & $232,739,673$ & $252,771,550$ & $223,231,975$ & $221,882,472$ \\
\hline
\end{tabular}

Source: National Regional Development Agency, 2012, p. 83.

Ratio analysis is often used as a tool of financial analysis within the agricultural sector (Katchova and Enlow, 2013). If we compare results from the previous two tables (microaspect: analysis of business success), we can see that the agricultural companies of Serbia have even 10 times higher share of financing responsibilities compared to Slovenia (growth of indebtedness), whereas they have even 3 times lower coefficient of stock turnover (poor sales and cash management). Long-term financial stability has been rated on the basis of the coefficient of long-term assets coverage (capability to finance longterm assets by long-term financing sources). If the value of this coefficient is below 1 , financial stability of a company has been impaired. In times of crisis, this indicator for both of the observed economies (for the agricultural sector) has recorded only a minimal value. The negative influence of crisis on the profitability of the agricultural sector (economical business operations, return on assets, and net margin) is evident in both countries. However, it is more pronounced in agricultural companies in Serbia. Financial expenditures of agricultural companies in Serbia are almost two times bigger than financial expenditures of agricultural companies in Slovenia (non - rational cost management). While the decrease or increase of industrial production or services can easily be observed month after month, agriculture - due to its specific nature - offers some extremely unreliable data for a short term, so it is very hard to identify the exact influence of crisis. What is more, changes in the way market chains operate increasingly higher sales thanks to supermarkets and specialized stores, all lead to an expanded market chain and thus a stronger influence of variable market flows on agriculture.

\section{Discussion - problem of harmonization}

As the experience of central-east European countries shows, the negotiating process and process of fulfilling conditions for a full-fledged membership in the European Union are extremely long and complex processes. An extremely "sensitive" area is agriculture and process of harmonization of national agriculture policies of future member countries with the 
existing mechanisms of the Common agricultural policy of the European Union (Banse et al., 2008). Given that a large part of legislative (determined at the level of EU) is focused on agriculture, and that a significant part of budget is used to finance complex mechanisms of the Common agricultural policy, it is no surprise that the process of adjustments and harmonization in the domain of agriculture play a significant role in the pre-accession negotiating processes. The system and pricing policy of agricultural and food products, measures of budgeting support, legislative, relevant institutions, crediting sources and investments in agriculture, as well as expert and consultancy services, are only some of a large number of questions which require adequate responses in the process of replacing the national agricultural policy with the Common agricultural policy of the European Union. Since entering the unified European market implies the acknowledgment of provisions of multilateral trade agreements, the membership of Serbia in the World trade organization should present a significant step preceding full-fledged membership in the European Union. Our country was deprived of member status in the World trade organization when the United Nations imposed economic sanctions on Serbia in 1992. To the present day, membership status has not yet been granted to Serbia (Marković, 2007).

The expansion of the European Union has also increased the level of diversification of agriculture and rural economy, and thus limited the possibilities of strict implementation of single legislative defined at the level of the EU. More pronounced regional and local differences among rural communities call for more flexible support mechanisms, which will provide sustainable agricultural and rural development. Instead of compromising solutions which are present on the whole of the EU territory and are nowhere completely satisfactory, it is better (from the perspective of the Union), to provide flexible frameworks within which adequate solutions for specific sectors and regions can be found (Popović and Katić, 2007).

Table 6. Reform index for the agricultural sector

\begin{tabular}{|c|c|}
\hline Country & Reform index for agricultural sector \\
\hline The Czech Republic & 9.2 \\
\hline Hungary & 9.2 \\
\hline Poland & 8.0 \\
\hline Slovakia & 8.2 \\
\hline Central Europe & 8.7 \\
\hline Albania & 6.8 \\
\hline Bulgaria & 8.0 \\
\hline Romania & 6.6 \\
\hline Slovenia & 9.2 \\
\hline The Balkans & 7.7 \\
\hline Estonia & 9.0 \\
\hline Latvia & 9.0 \\
\hline Lithuania & 8.0 \\
\hline The Baltic countries & 8.7 \\
\hline Belorussia & 1.8 \\
\hline Moldova & 6.0 \\
\hline
\end{tabular}




\begin{tabular}{|l|c|}
\hline \multicolumn{1}{|c|}{ Country } & Reform index for agricultural sector \\
\hline Russia & 5.8 \\
\hline Ukraine & 6.0 \\
\hline \multicolumn{1}{|c|}{ Commonwealth of Independent States (Europe) } & $\mathbf{4 . 9}$ \\
\hline Kazakhstan & 5.8 \\
\hline Kyrgyzstan & 6.2 \\
\hline Tajikistan & 4.8 \\
\hline Turkmenistan & 2.0 \\
\hline Uzbekistan & 3.4 \\
\hline Commonwealth of Independent States (Central Asia) & $\mathbf{4 . 4}$ \\
\hline
\end{tabular}

Source: Swinnen, 2004, p. 13.

In the coming years, Serbia should adjust the domestic agricultural policy and harmonize it with the Common agricultural policy, in terms of the measures which are necessary to implement, as well as amounts allocated to stimulate the development of agriculture. It is necessary to harmonize measures of the domestic agricultural policy with the measures of the Common agricultural policy of the European Union, so that responsibilities of some future membership do not cause fatal consequences for the domestic agriculture. This implies the creation of measures which are in accordance with the already existing ones in the EU, while at the same time anticipating the future measures of the Common agricultural policy.

Although Serbia has rich natural resources, in many areas both industry and farms lack modern technology, and strongly need technical improvements and increased financial resources for further development (Urban-Rural Disparities). As a result of weakness in technology and access to finance, Serbia does not have productivity on the level of the EU, or, in many cases even on the level of its neighbors.

Graph 5. Regional economic disparities in Serbia (gap between developed north and underdeveloped south) - the agrarian aspect
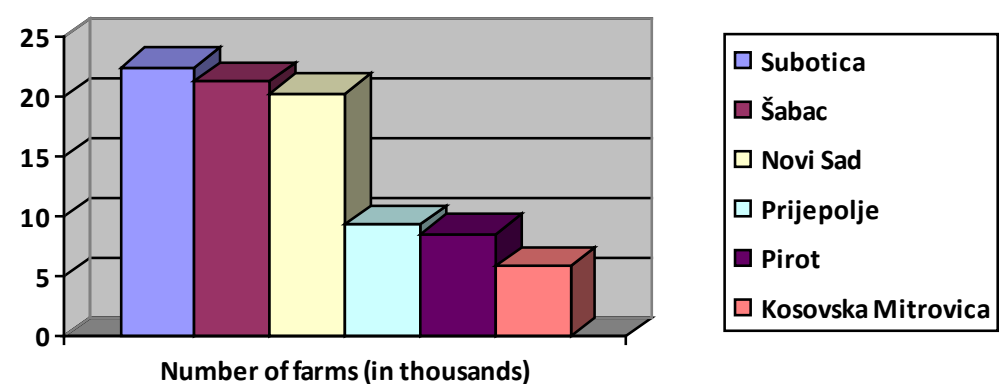

Source: Author's analysis, based on data from the Treasury of The Republic of Serbia, 2012.

Because of the time-lag between the payment for variable agricultural inputs and obtaining revenues from sale of production the farm has a demand for the short-term credit. The demand for credit can be satisfied either internally (cash flow, savings, subsidy) or externally (bank loan, or trade credit), (Ciaian et al., 2011). Subsidies may increase bank loans, reduce 
them or have no impact on bank loans depending on whether farms are credit constrained, whether subsidies are allocated at the beginning or at the end of the growing season, and on the relative cost of internal and external financing (Ciaian et al., 2011). Finance matters for sustainable export performance. Subsidies can be distributed among individuals according to a set of selected criteria: level of income, social group, merit, etc. Two types of errors arise if proper subsidy targeting is not done (exclusion and inclusion errors): in the former case, some of those who deserve to receive a subsidy are excluded, and in the latter case, some of those who do not deserve to receive subsidy get included in the subsidy programme. For example, in 2009, Serbia was within top ten largest world exporter of corn. Being so important factor in Serbian economy, it is expected that there is a need for future high investments in agribusiness sector. Since domestic sources are very limited, the other possibility is to attract foreign investors.

Graph 6. Export potentials of Serbia (US Dollar thousand) - the agrarian aspect
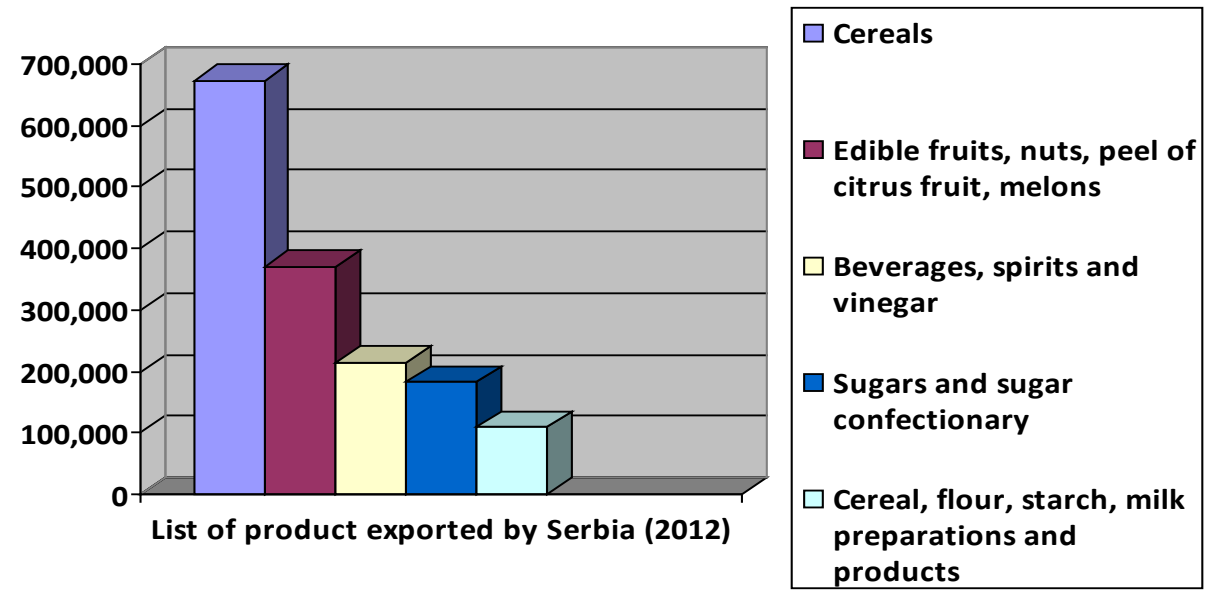

Source: Author's analysis, based on data from the International Trade Centre, 2012.

Table 7. SWOT analysis - Role of innovative sources of finance in the agricultural development of Serbia

\begin{tabular}{|c|c|}
\hline NGTHS & WEAKNESSES \\
\hline $\begin{array}{l}\text { Favorable geographic location and pleasant climate } \\
\text {. Strengthening of investment predispositions } \\
\text {. Privatization process (increase of capital base) } \\
\text {. Participation in making of the all-encompassing EU strategy } \\
\text { for the Danube region } \\
\text {. Increased number of financial resources from IPA funds } \\
\text { - More intensive across-border cooperation } \\
\text { - Slight expansion of financial market } \\
\text { - Positive example of a company "Foodland" as a motivating } \\
\text { factor - "World Star" award for the product "Bakina tajna" } \\
\text { (eng. Granny's secret) - for the world's best product package) }\end{array}$ & $\begin{array}{l}\text { Privatization difficulties } \\
\text { - } \text { Lack of strategic partnerships } \\
\text { - } \text { High unemployment } \\
\text { - } \text { High public debt } \\
\text { - Uncompetitiveness and insolvency of economy } \\
\text { - Insufficient knowledge about the importance of } \\
\text { technological innovations in economy } \\
\text { - Financial crisis and crisis of trust } \\
\text { - Decrease of living standard (fall of demand) } \\
\text { - Neglect of local development potentials (tradition and } \\
\text { resource structure) } \\
\text { - Overly fragmented farming estates } \\
\text { - Undeveloped cooperatives (poor organization of } \\
\text { agricultural producers) } \\
\text { High interest rates for agricultural credits }\end{array}$ \\
\hline
\end{tabular}




\begin{tabular}{|c|c|}
\hline OPPORTUNITIES & THREATS \\
\hline 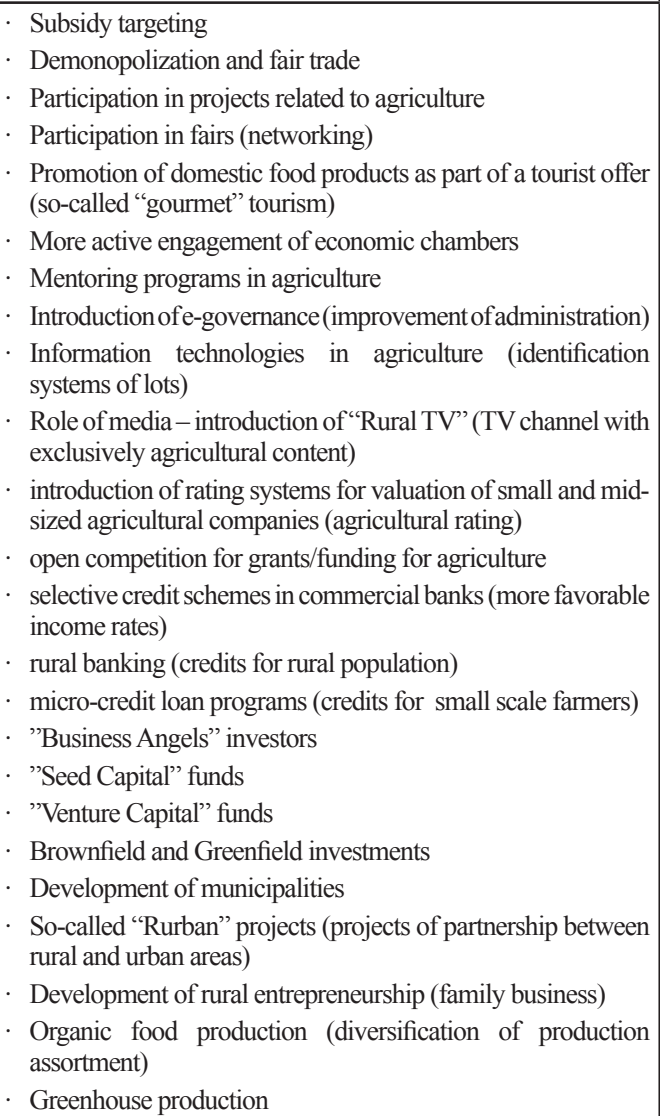 & 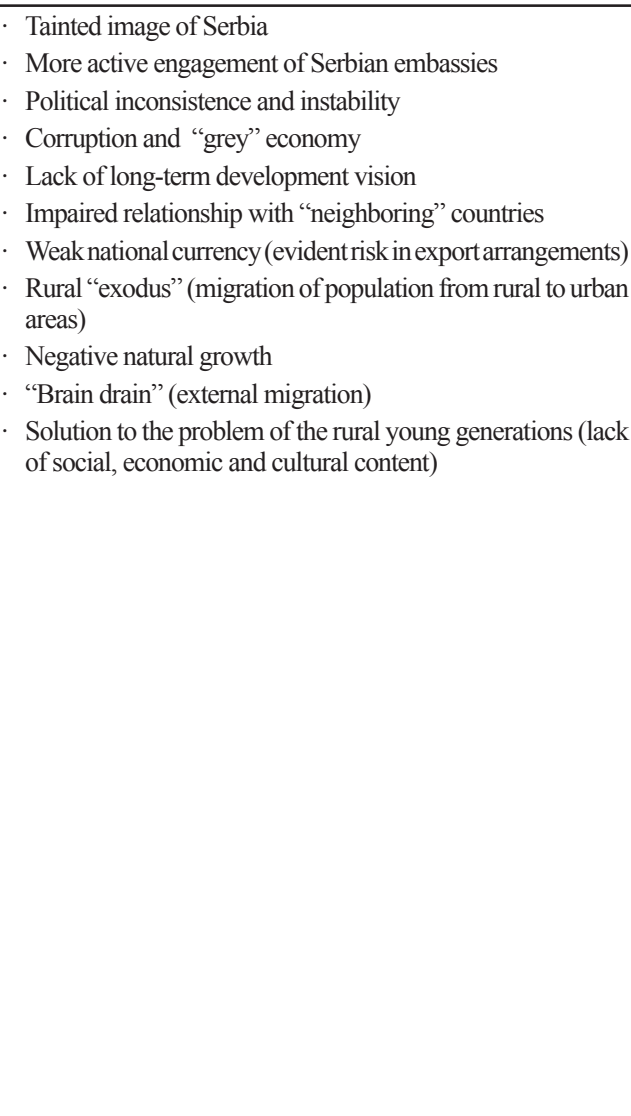 \\
\hline
\end{tabular}

Source: Authors.

Hence, the development of a profitable, economically sustainable agriculture is an attainable goal. However, it is necessary to reform agricultural structure first, regulate the agricultural products market, develop a system of capital investments, create a logistic platform and strengthen education. The area dealing with agricultural finances could be defined as a dynamic, and functional utilization of resources - monetary (savings, subsidies and loans), as well as non-monetary ones (production factors), (Cabannes, 2012).

\section{Conclusion}

Despite the fact that farming area covers around $60 \%$ of the total territory of Serbia, and that $43 \%$ of the total population lives in rural areas, the agricultural sector is continuously being neglected. On the other hand, the importance of rural development is continuously growing in the European Union, year after year. Apart from economic and political, there are also social reasons and reasons connected with health and wellbeing which contribute to this agenda. The Common agricultural policy is the oldest and most carefully reformed common policy of a sector. Nowadays, even more than $40 \%$ of the EU budget is spent on financing 
various agricultural programs (this is over 50 billion euros per year), which only emphasizes their importance. Formally seen, the main objectives of the Common agricultural policy have not changed since the beginning of the European integrations process. However, over the last fifteen years of reforms, the multi-purpose nature of European agriculture has been put to the foreground, which indicates that the agricultural policy has a "new face". Numerous external effects are now connected with agriculture. A popular name for this new concept of Common agricultural policy is the "European model of agriculture" or "sustainable agriculture". Climate changes, together with global food problems and issues related to energy security do not let us lose interest in agriculture and rural development in general. Hence, we should focus our attention on a "Copernican shift" of instruments and support mechanisms instead.

\section{References}

1. Babović, J., Veselinović, B. (2010): Agrarna politika EU i prilagođavanje agrara Srbije, Društveni izazovi evropskih integracija - Srbije i uporedna iskustva, Fakultet za pravne i poslovne studije, Novi Sad, pp. 195-206.

2. Banse, M., Helming, J. F. M., Nowicki, P., Van Meijl, H. (2008): Future of European agriculture after the Health Check, German Journal of Agricultural Economics, vol. 57(3/4), pp. 156-164, available on: http://ageconsearch.umn.edu/bitstream/97588/2/2 Banse.pdf

3. Cabannes, Y. (2012): Financing Urban Agriculture, Environment and Urbanization, vol. 24 (2), pp. 665-683, available on: http://eau.sagepub.com/content/24/2/665.full.pdf $+\mathrm{html}$

4. Ciaian, P., Falkowski, J., Kancs, d'A. (2010): Access to Credit, Factor Allocation and Farm Productivity: Evidence From the CEE Transition Economies, $114^{\text {th }}$ Seminar of the European Association of Agricultural Economists (EAAE), Proceedings, Berlin, Germany, pp. 1-35, available on: http://ageconsearch.umn.edu/bitstream/61347/2/Ciaian\%20 Falkowski\%20Kancs\%2061347.pdf

5. Ciaian, P., Pokrivcak, J., Szegenyova, K. (2011): Do Agricultural Subsidies Crowdout or Stimulate Rural Credit Market Institutions?: The Case of CAP Payments, 2011 AAEA and NAREA Joint Annual Meeting, Pittsburgh, pp. 1-27, available on: http:// ageconsearch.umn.edu/bitstream/103085/2/Paper.pdf

6. Curtiss, J. (2012): Determinants of Financial Capital Use: Review of Theories and Implications for Rural Businesses, Factor Markets Working Papers, No. 123, Centre for European Policy Studies, Brussels, Belgium, pp. 1-51, available on: http://ageconsearch. umn.edu/bitstream/122846/2/FM WP19\%20Determinants $\% 20$ of $\% 20$ financial $\% 20$ capital\%20use.pdf

7. Financial framework 2007-2013 (2012, July 10), available on: http://ec.europa.eu/ budget/figures/2010/2010 en.cfm

8. Hedman, K., Lagerqvist, C. J. (2013): Performance Indicators in Agricultural Financial Markets, Factor Markets Working Paper No. 43, Centre for European Policy Studies, Brussels, Belgium, pp. 1-28, available on: www.ceps.eu/book/performance-indicatorsagricultural-financial-markets 
9. Katchova, A. L., Enlow, S. J. (2013): Financial performance of publicly-traded agribusinesses, Agricultural Finance Review, vol. 73 (1), pp. 58-73, available on: http://ageconsearch.umn.edu/bitstream/164518/2/Agribusiness\%20Financial\%20 Performance.pdf

10.Marković, K. (2007): Transformacija Zajedničke agrarne politike Evropske Unije i implikacije na poljoprivredu Srbije, doktorska disertacija, Ekonomski fakultet Subotica, Subotica.

11. Martini, R. (2011): Long Term Trends in Agricultural Policy Impacts, OECD Food, Agriculture and Fisheries Papers, No. 45, OECD Publishing, pp. 1-102, available on: www.oecd-ilibrary.org/ docserver/download $/ 5 \mathrm{kgdp} 5 \mathrm{zw} 179$ q.pdf?expires=1408612555\&id=id\&accname=guest\&check sum=80034D2A25F3621EFA0EE45F863B3AFA

12. Ministarstvo finansija Republike Srbije (2012, July 13), available on: www.mfp.gov.rs/ pages/issue.php?id $=1578$

13. Mondelli, M. P. (2012): The Determinants of External Private Equity Financing in Agricultural Production Businesses, 27 th International Conference of Agricultural Economists, Proceedings, Foz do Iguaçu, Brazil, pp. 1-27, available on: http:// ageconsearch.umn.edu/bitstream/127135/2/Mondelli_2012_Determinants\%20 External\%20Equity\%20Finance\%20in\%20Agriculture IAAE AgEconSearch.pdf

14. Morgan, W., Cotter, J., Dowd, K. (2011): Extreme Measures of Agricultural Financial Risk, Quantitative finance, Vol. 4, pp. 1-39, available on: http://arxiv.org/ftp/arxiv/ papers/1103/1103.5962.pdf

15. Nacionalna agencija za regionalni razvoj (2012): Uticaj finansijske krize na poslovne performanse preduzeća po privrednim granama - komparativna analiza Srbije, Hrvatske i Slovenija, Beograd, available on: http://narr.gov.rs/index.php/content/ download/1604/8664/file/Uticaj\%20finansijske\%20krize,\%20web.pdf

16. O'Toole, C., Newman, C., Hennessy, T. (2014): Financing Constraints and Agricultural Investment: Effects of the Irish Financial Crisis, Journal of Agricultural Economics, vol. 65(1), pp. 152-176, available on: http://onlinelibrary.wiley.com/doi/10.1111/1477-9552.12027/pdf

17.Pejanović, R., Milanović, M., Cvijanović, D. (2006): Transition of agriculture in the Republic of Serbia, Ekonomika poljoprivrede, IAE Belgrade, vol. 53 (4), pp. 937-946.

18. Pietola, K., Myyra, S., Heikkila, A. (2011): The penetration of financial instability in agricultural credit and leveraging, Centre for European Policy Studies (Brussels, Belgium), Factor Markets (Project), No. 2, pp. 1-20, available on: http://ceps.be/book/ penetration-financial-instability-agricultural-credit-and-leveraging

19. Popović, V., Katić, B. (2007): Nivo i struktura interne podrške poljoprivredi Srbije u procesu pristupanja STO i EU, monografija, IEP, Beograd.

20. Radović, G. (2009): Podrška države u funkciji finansiranja poljoprivrede, Agroekonomika, vol. 38 (41-42), pp. 69-79.

21. Radović, G. (2011): Model tranzicije slovenačke poljoprivrede, Škola biznisa, vol. 8 (1), pp. 101-113. 
22. Reyes, A., Lensink, R., Kuyvenhoven, A., Moll, H. (2012): Dynamics of Investment for Market-Oriented Farmers in Chile, $28^{\text {th }}$ International Conference of Agricultural Economists, Proceedings, Foz do Iguaçu, Brazil, pp. 1-38, available on: http:// ageconsearch.umn.edu/bitstream/126218/2/Dynamics\%20of\%20investment.pdf

23. Stiglitz, J., Jaramillo-Vallejo, J., Chal Park, Y. (1994): The Role of the State in Financial Markets, World Bank Research Observer, Annual Conference on Development Economics Supplement, pp. 19-61, available on: http:/www-wds.worldbank.org/ servlet/WDSContentServer/WDSP/IB/1994/03/01/000009265_3970702134931/ Rendered/PDF/multi_page.pdf

24. Swinnen, J. (2004): Policy Reform and Agricultural Adjustment in Transition Countries, International Agricultural Trade Research Consortium - Adjusting to Domestic and International Agricultural Policy Reform in Industrial Countries, Philadelphia, pp. 1-25, available on: http://ageconsearch.umn.edu/bitstream/15761/1/cp04sw01.pdf

25.Swinnen, J., Gow, H. (1997): Agricultural credit problems and policies during the transition to a market economy in Central and Eastern Europe, Policy Research Group, Working Paper No. 6, pp. 1-32, available on: http://ageconsearch.umn.edu/ bitstream/31887/1/prg-wp06.pdf

26. Veselinović, B., Ševarlić, M., Todorović, M. (2007): Village Tourism as Generator of Rural Development in Serbia: Situation and Perspectives, Thematics Proceedings from $100^{\text {th }}$ Seminar of the EAAE, EAAE and DAES, Novi Sad, pp. 397-402.

27. Weber, R., Musshoff, O., Petrick, M. (2014): How Flexible Repayment Schedules Affect Credit Risk in Microfinance, Paper presented at the International Agricultural Risk, Finance and Insurance Conference (IARFIC), Vancouver, Canada, Diskussionspapiere, Department für Agrarökonomie und Rurale Entwicklung, No. 1404, pp. 1-35, avaiable on: http://econstor.eu/bitstream/10419/96512/1/783944519.pdf

28.Zhao, J., Barry, P., Katchova, A. (2008): Signaling Credit Risk in Agriculture: Implications for Capital Structure Analysis, Journal of Agricultural and Applied Economics, vol. 40 (3), pp. 805-820, available on: http://ageconsearch.umn.edu/ bitstream/47260/2/jaae-40-03-805.pdf 


\title{
KVALITATIVNA I KVANTITATIVNA ANALIZA MIKRO I MAKRO ASPEKTA AGRARNIH FINANSIJA
}

\author{
Branislav Veselinović3, Maja Drobnjaković ${ }^{4}$
}

\begin{abstract}
Sažetak
Epicentar ove analize jeste da pruži pregled trenutnog stanja u mikro i makro agrarnim finansijama u Srbiji i EU. Jedan od ciljeva ovog istraživanja jeste da se razmotre slabosti i potencijali agrarne politike u Srbiji, kroz poređenje sa razvijenijim zemljama. U ovoj kvalitativnoj i kvantitativnoj analizi, autori su koristili metod komparacije, metod analize i sinteze, induktivni i deduktivni metod, kao i pregled domaće i međunarodne literature. Postoji nekoliko važnih zaključaka koji mogu da se izvuku iz ovog rukopisa. Poljoprivrednici i poljoprivredna MSP imaju najslabiji pristup finansijskim sredstvima, od svih sektora $u$ Srbiji. Finansijski sektor Srbije nudi siromašan opseg kreditnih proizvoda poljoprivrednom sektoru. Dakle, postojeći mehanizmi za mikro i makro agrarne finansije u Srbiji nisu adekvatni i promena bi trebalo da bude napravljena u samom pristupu.
\end{abstract}

Ključne reči: poljoprivreda, finansije, Srbija, EU, harmonizacija.

3 Prof. dr Branislav Veselinović, redovni profesor, Fakultet za ekonomiju i inženjerski menadžment - Univerzitet Privredna akademija u Novom Sadu, Cvećarska br. 2, 21000 Novi Sad, Republika Srbija, Telefon: +381 63505 350, E-mail: bveselinovic@fimek.edu.rs

4 Msr. Maja Drobnjaković, asistent, Fakultet za ekonomiju i inženjerski menadžment-Univerzitet Privredna akademija u Novom Sadu, Cvećarska br. 2, 21000 Novi Sad, Republika Srbija, Telefon: +381 6423760 32, E-mail: majadrobnjakovic@,fimek.edu.rs 